Check for updates

The BMJ

Cite this as: $B M / 2021 ; 375: \mathrm{n} 3116$ http://dx.doi.org/10.1136/bmj.n3116 Published: 18 December 2021

\section{Covid-19: Advise public to reduce social contacts to keep NHS running, say health leaders}

\author{
Gareth lacobucci
}

Medical leaders and experts have urged the Westminster government to implement further protective measures against covid-19 immediately to try to halt the rapid acceleration of omicron cases that threatens to overwhelm the health service. These should include reducing levels of social contact, they advised.

The BMA warned that 50 ooo doctors, nurses, and other NHS staff in England could be off sick with covid-19 by Christmas Day if the government fails to introduce further measures to stop the virus spreading, citing its analysis of current case numbers and trends.

The UK recorded 93045 new covid-19 cases on 17 December. Although reports from South Africa suggest that symptoms with the omicron variant are less severe than with earlier variants, commentators have warned that the number of people infected could easily overwhelm hospitals.

Chaand Nagpaul, BMA council chair, said that escalating workforce shortages would severely limit the health service's ability to provide care to patients. "We're already seeing services being affected by staff absences, and these estimates show it could get far, far worse," he warned.

Without enough staff, appointments and treatments would need to be cancelled or postponed, he added, and waits for care in GP surgeries and hospitals would rise further, all of which could affect the delivery of the vaccine booster programme.

"The government should recall MPs next week to give the NHS the protections it needs," said Nagpaul.

"These would mean cancelling large indoor gatherings, reintroduction of the two metre social distancing rule, and sending a strong message to the public to limit social mixing, especially ahead of Christmas when we know people will want to see their families and loved ones.”

The BMA also called for clearer messaging on taking lateral flow tests before mixing, mandatory mask wearing, and ensuring adequate ventilation for gatherings, and it urged the government to provide financial support to businesses affected by additional restrictions.

The latest NHS data show a 9\% increase in covid related staff absences at NHS trusts in England from 5 to 12 December, ${ }^{1}$ and London saw the biggest rise of $40 \%$ between these two dates (see table). The effect is also being seen by locum agencies: NHS Professionals has seen demand for locum doctors rise by $20 \%$ on this time last year.

Juliette Cosgrove, chief nurse at NHS Professionals, which supplies mostly to medical specialties, said, "The requirements are for all grades in emergency medicine, respiratory consultants as you'd expect, and all middle grades for critical care specialties." She said that it was not always possible to fill shifts.

\section{New restrictions}

On 16 December Wales announced new restrictions effective from 27 December to try to control the spread of the omicron variant. ${ }^{2}$ These will include a two metre rule on social distancing in offices and extra measures to protect customers and staff, such as one way systems and physical barriers. Nightclubs will also close.

Independent Sage called for "an immediate circuit break" and then limited mixing at Christmas from 25 to 28 December, ${ }^{3}$ which would mean closing indoor hospitality and entertainment, no indoor gatherings between households of any size (excepting "bubbled" individuals and other roadmap exceptions), all close contacts of new cases isolating for 10 days, and adequate financial support for the businesses affected.

Martin McKee, a member of Independent Sage and professor of European public health at the London School of Hygiene and Tropical Medicine, said that the virus's impact on NHS staff absences made immediate action "essential."

"The speed with which this wave is increasing is unprecedented," he said. "With very high case numbers at once it is bound to have a major impact on critical infrastructure, and especially the NHS."

On 15 December the UK Health Security Agency updated its guidance for healthcare professionals who come into contact with someone with the omicron variant. ${ }^{4}$ If healthcare staff are fully vaccinated they are now required to isolate only if they test positive or develop symptoms.

But even with the rules on isolating relaxed, said McKee, many staff would still become infected and have to isolate. "The loss of a single specialist can make an entire team non-viable," he warned. "This will have consequences for all patients, not just those with covid, and could create a major crisis in certain facilities.” 


\section{Table | Covid-19 related staff absences (through sickness or self-isolation) from NHS acute trusts}

\begin{tabular}{|c|c|c|c|}
\hline Region & Covid related staff absenc & f absences on 12 Dec 2021 & Change from previous week (\%) \\
\hline England & 11233 & 12240 & +9 \\
\hline East of England & 846 & 1088 & +29 \\
\hline London & 1100 & 1540 & +40 \\
\hline Midlands & 2705 & 2823 & +4 \\
\hline North East and Yorkshire & 2139 & 2089 & -2 \\
\hline North West & 1709 & 1963 & +15 \\
\hline South East & 1399 & 1361 & -3 \\
\hline South West & 1335 & 1376 & +3 \\
\hline
\end{tabular}

$1 \quad$ NHS England. Urgent and emergency care daily situation reports 2021-22. https://www.england.nhs.uk/statistics/statistical-work-areas/uec-sitrep/urgent-and-emergency-care-daily-situationreports-2021-22/

2 Welsh Government. New advice to keep Wales safe this Christmas. Updated 16 Dec 2021. https://gov.wales/new-advice-keep-wales-safe-christmas

3 Independent Sage. Emergency statement on omicron. 15 Dec 2021. https://www.independentsage.org/emergency-statement-on-omicron-15-december-2021/

4 UK Health Security Agency. Guidance. Covid-19: management of staff and exposed patients or residents in health and social care settings. Updated 15 Dec 2021. https://www.gov.uk/government/publications/covid-19-management-of-exposed-healthcare-workers-and-patients-in-hospital-settings/covid-19-management-of-exposed-healthcare-workers-and-patients-in-hospitalsettings\#fn:1

This article is made freely available for use in accordance with BMJ's website terms and conditions for the duration of the covid-19 pandemic or until otherwise determined by BMJ. You may use, download and print the article for any lawful, non-commercial purpose (including text and data mining) provided that all copyright notices and trade marks are retained. 